\title{
Article
}

\section{Ojo Guareña: A Hotspot of Subterranean Biodiversity in Spain}

\author{
Ana Isabel Camacho ${ }^{1, *(1)}$ and Carlos Puch ${ }^{2}$ \\ 1 Dpto. Biodiversidad y Biología Evolutiva, Museo Nacional de Ciencias Naturales (CSIC), \\ José Gutiérrez Abascal 2, 28006 Madrid, Spain \\ 2 Grupo Espeleológico Edelweiss, Club Cántabro de Exploraciones Subterráneas, Víctor de la Serna 26, \\ 28016 Madrid, Spain; carlospuch@gmail.com \\ * Correspondence: mcnac22@mncn.csic.es
}

Citation: Camacho, A.I.; Puch, C. Ojo Guareña: A Hotspot of Subterranean Biodiversity in Spain. Diversity 2021, 13, 199. https:// doi.org/10.3390/d13050199

Academic Editors: Tanja Pipan, David C. Culver and Louis Deharveng

Received: 31 March 2021

Accepted: 6 May 2021

Published: 8 May 2021

Publisher's Note: MDPI stays neutral with regard to jurisdictional claims in published maps and institutional affiliations.

Copyright: (c) 2021 by the authors. Licensee MDPI, Basel, Switzerland. This article is an open access article distributed under the terms and conditions of the Creative Commons Attribution (CC BY) license (https:// creativecommons.org/licenses/by/ $4.0 /)$.

\begin{abstract}
Ojo Guareña Natural Monument in Burgos (Spain) is an important and large karstic system. It consists of more than $110 \mathrm{~km}$ of surveyed galleries, and it has rich sources of organic material from the surface and permanent water circulation. It is the fourth largest cave system in the Iberian Peninsula, and one of the 10 largest in Europe. Ojo Guareña also ranks 23rd among the world's largest caves. To date, only volcanic caves in the Canary Islands, in which between 28 and 38 subterranean species occur, are considered subterranean diversity hotspots in Spain. Here, we provide the first list of subterranean taxa present in Ojo Guareñ, which is comprised of 54 taxa that includes 46 stygobiotic and eight troglobiotic species (some still unidentified at the species level), revealing Ojo Guareña as the largest known subterranean biodiversity hotspot in Spain and Portugal. In addition, we provide a list of an additional 48 taxa, 34 stygophiles and 14 troglophiles, found in the system, whose ecological status could change with detailed biological studies, which may change the number of strictly subterranean species present in the system. Indeed, at present, these numbers are provisional as they correspond to a small part of this sizeable cave system. The biodiversity of large areas of the system remains unknown as these areas have yet to be explored from the biological point of view. In addition, a large number of samples of both terrestrial and aquatic fauna are still under study by specialists. Furthermore, evidence of cryptic species within Bathynellacea (Crustacea) indicates an underestimation of biodiversity in the karstic system. Despite these limitations, the data available reveal the typical uneven distribution of subterranean aquatic fauna, and suggest that the great heterogeneity of the microhabitats in this wide and highly connected karstic extension led to the great richness of aquatic subterranean species.
\end{abstract}

Keywords: hotspot caves; Ojo Guareña natural monument; stygobionts; troglobionts; subterranean biodiversity

\section{Introduction}

Iberian Peninsula, together with Balearic Islands, is one of the regions in Europe with the greatest development of karst areas. Numerous caves, many of them large (more than $3 \mathrm{~km}$ of development and/or more than $300 \mathrm{~m}$ in depth), have been surveyed in the country [1]. Despite this, very little data on the subterranean fauna within these caves are available. Potential biospeleologists are discouraged by the difficulties of access and progression in the caves (e.g., large vertical shafts, meanders, narrow passages, etc.), the inaccessibility to man of much of the underground environment (flooded galleries, mesovoid shallow substratum-MSS-, hyporheic sites), and the low density of specimens in accessible populations (epikarst, especially). Thus, most samplings of these ecosystems have been limited and sporadic, and mainly focused on the study of specific taxonomic groups using capture techniques suited for them. Due to the great sampling deficiencies and the scarce biospeleological tradition in our country, there are very few inventories of the region's underground fauna beyond some lists of a few terrestrial or aquatic taxa in the more well-known caves. The only caves considered in the literature as subterranean diversity 
hotspots in Spain are four volcanic ones located in the Canary Islands: in these, between 28 and 36 troglobiotic species and 38 stygobiotic and interstitial species (volcanic anchialine habitats of Lanzarote) have been recorded [2,3]. Culver and Pipan (2013) also mention possible diversity hotspots in the Cantabrian Mountains in northern Spain, which contain the largest number of caves in the country [4]; however, more studies of this region are needed to confirm this hypothesis.

The Ojo Guareña Natural Monument (OGNM) karstic system is situated on the southern rim of the Cantabrian Mountains. It lies within a hypothetical zone (between ca $42^{\circ}$ and $46^{\circ} \mathrm{N}$ ) in Europe characterized as having "high biodiversity for terrestrial cave fauna" [5]. According to Gulden [6], OGNM is the fourth largest cave system in the Iberian Peninsula, and one of the 10 largest in Europe; it also ranks 23rd on the list of the world's largest caves. With more than $110 \mathrm{~km}$ of surveyed galleries, it is a vast cave system that has rich sources of organic material from the surface and also permanent groundwater flow (phreatic water). It is one of the few places in Spain where the terrestrial and aquatic environments have been sampled repeatedly and extensively [7]. However, we are far from knowing its true diversity. All of the "shortfalls" impeding our knowledge of biodiversity that are commonly mentioned at the global level (e.g., Linnean, Wallacean, Darwinian, Prestonian) [8] also apply at local scales. A more recently described shortfall, the "Racovitzan impediment" [9], is of particular importance in the case of the subterranean biodiversity of the OGNM: what remains unexplored, from a biological point of view, cannot be known.

The most accessible (and thus the best sampled) area of the OGNM extends from the main entrance at Palomera Cave to Museo de Cera Hall (covering about $3 \mathrm{~km}$ of passages). Moreover, this area contains sumps from the Guareña River and water that filters in from the Trema River. However, many of the specimens collected in this area and throughout the monument remain unidentified at the species level (taxonomic shortfall). Cryptic species of crustaceans have also been discovered in the area [10], indicating that the data presented here represent an underestimation of the diversity of the subterranean fauna. In addition, the biological composition of many kilometers of underground passages has yet to be surveyed, and the accumulation curves of stygobitic species $[7,11]$ of the best sampled areas do not reach saturation, demonstrating our incomplete knowledge of the true biodiversity of this cave system's fauna.

In addition to its biological assemblages, the OG endokarst has unique geological, geomorphological, hydrological, paleoclimatic, archaeological, and paleontological characteristics that make it worthy of protection. It has a continuous and non-fragmented surface that is subjected to natural evolution with little human intervention and that can maintain the physical and biological characteristics of the system, ensuring the continued functioning of natural processes. Moreover, the absence of resource extraction by agricultural, forestry, hydraulic or mining (natural or artificial) activities reduce the likelihood that the functioning and resources of the ecosystems within the system, and the aesthetics of the landscape, would be significantly altered.

\section{A Bit of History}

The main cave of the system (OG), through its main entrances (Palomera Cave and Dolencias Shaft), has been known since the 1940s [4]. Although the cave did not initially arouse great interest among the scientific community-beyond simple sporadic visits and specific samplings-, interest later increased as the importance of its biological species [12-15], archaeological sites [16], and hydrogeological and geomorphological peculiarities became more evident. Due to these features, various public administrations began to establish general protection regimes for the karst system; eventually, in 1996, it was incorporated as a natural monument in the Network of Protected Natural Spaces in Spain and, more recently, in the European Ecological Network Natura 2000 [7]. In addition, given the uniqueness of its geology, it was included in a publication on the "Points of Geological Interest of the Cantabrian Coast" (1983). However, despite these acknowledgments, very 
little scientific study has been conducted in the system. In fact, until just this century, faunal sampling of the system had been sparse, and the findings almost anecdotal.

Here, we provide some details of past explorations of this natural monument in order to put into context the knowledge that exists of this vast karst system. The presence of numerous archaeological remains from the Paleolithic and Neolithic, and from the Iron and Middle ages, testifies that OG has been known since ancient times. However, geologists did not become interested in it until 1933 [17]. In 1956, the Edelweiss Cave Club (GEE), from Burgos, began to explore the large galleries that converge at the main entrance (development $=8 \mathrm{~km}$ ). In 1958, with the collaboration of various speleological groups (Spanish and foreigners), the "OG 58" campaign was held, resulting in $8900 \mathrm{~m}$ being surveyed and produced the first plan of the cave. A complete topographic survey of the system continues to this day, and in parallel, exploration inside the main cave and the rest of the caves intensifies. By 1986 [18], surveys of new sectors, only accessible when the water is low, together with the union of other caves, considerably increased the known development of the complex to $89,071 \mathrm{~m}$. Currently, $110 \mathrm{~km}$ in an area encompassing $15 \mathrm{~km}^{2}$ have been explored and surveyed.

Biological sampling of OG was occasional during the second half of the twentieth century, though it is worth highlighting the initiative of Professor Eugenio Ortiz, director of the Museo Nacional de Ciencias Naturales de Madrid (MNCN), who, from 1968 to 1975 , tried to establish an underground laboratory at the system (that never materialized) and an associated biological station to be sponsored by the Consejo Superior de Investigaciones Científicas (CSIC). Among the aquatic faunal samplings carried out during those years, Ortiz observed the presence of numerous specimens of the isopod Stenasellus virei buchneri Stammer, 1936 (Figure 1) in a pond near the Palomera entrance. He also collected specimens of Bathynellacea and some other groups; however, they were never studied or, at least, the results were never published. Other samples collected by Ortiz, especially terrestrial ones, were later studied by specialists of different fauna groups (e.g., oligochaetes, opilions, mites, myriapods, and beetles). Later (1975), T. Antón, a member of the Edelweiss Cave Club, and X. Bellés collected and studied some other terrestrial fauna, which led to several publications [19-26]. In 1984, Notenboom [27,28] reported on some aquatic faunal samples from one of the resurgences of the system (La Torcona). Camacho and Puch also conducted sporadic samplings of aquatic fauna in the cave during the 1980s and 1990s. Thanks to these works, which were performed without institutional support, the cave's fauna began to be inventoried [29]. As of 1993, a total of 81 taxa were known in the cave, of which 71 were identified to the species level (63 terrestrial and 8 aquatic). Of these, only a dozen of the well-identified species could be considered as strictly subterranean fauna [29]. From 2002 to 2004, OGNM was one of four areas under study as part of a project on European stygofauna (PASCALIS) [11]. The project areas included various caves, springs, wells, unsaturated zones (hyporheic system of epigean rivers) and porous aquifers. Finally, the Junta de Castilla y León and the MNCN of the CSIC signed agreements to carry out faunistic studies of the cave (from 2002 to 2004 and 2006 to 2009) prior to its limited opening to tourism. Small parts of the terrestrial [30] and aquatic ecosystems [31] were studied prior to any potential effects that tourism could have on the faunal composition. The results of all of these investigations have contributed to the lists of species constituting the main objective of this publication.

In this study, we provide the first lists of stygobiotic and troglobiotic (and stygophilic and troglophilic) taxa present in OGNM, which were compiled on the basis of the results of the aforementioned investigations. Although only a small fraction of this vast karst system has been surveyed, and some gaps in knowledge remain, we show that it is a hotspot of subterranean biodiversity with great biological potential. 


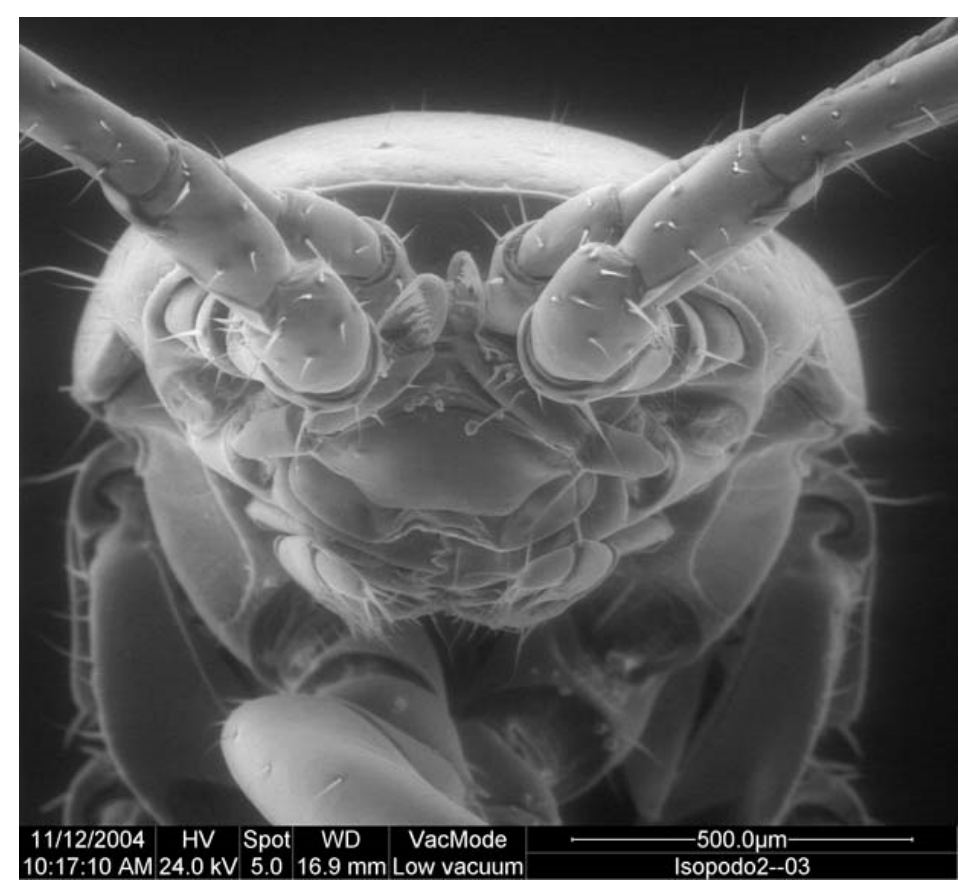

Figure 1. Isopod Stenasellus virei buchneri. Photo ESEM, MNCN, Madrid.

\section{Materials and Methods}

The study area (OGNM) is located in the Sotoscueva region (Burgos, Northern Spain), within the southernmost limit of the Cantabrian Mountains. OGNM is a paradigmatic example of a complete karst system, with a water absorption zone in the northwestern and central parts, an extensive network of galleries of more than $110 \mathrm{~km}$ in the main cave and evacuation points located at the southeastern limit of the system. It develops in limestones and dolomites of the Upper Coniacian (about 130 m of thickness), which lean on clay limestones and marls of the Middle Coniacian-Turonian (Upper Cretaceous) that act as an impermeable substrate (Figure 2). The surface landscape is arranged in the form of a geosyncline with a WNW-ESE alignment, giving rise to the characteristic slopes that stand out in the northern part of the area $[4,18,32]$. The rivers Guareña, to the north, and Trema, to the west, course underground when they encounter limestones and dolomites and resurface, after a long, partially known route, in La Torcona, a cave resurgence near the confluence of the Trema River with La Hoz Stream (Figure 3).

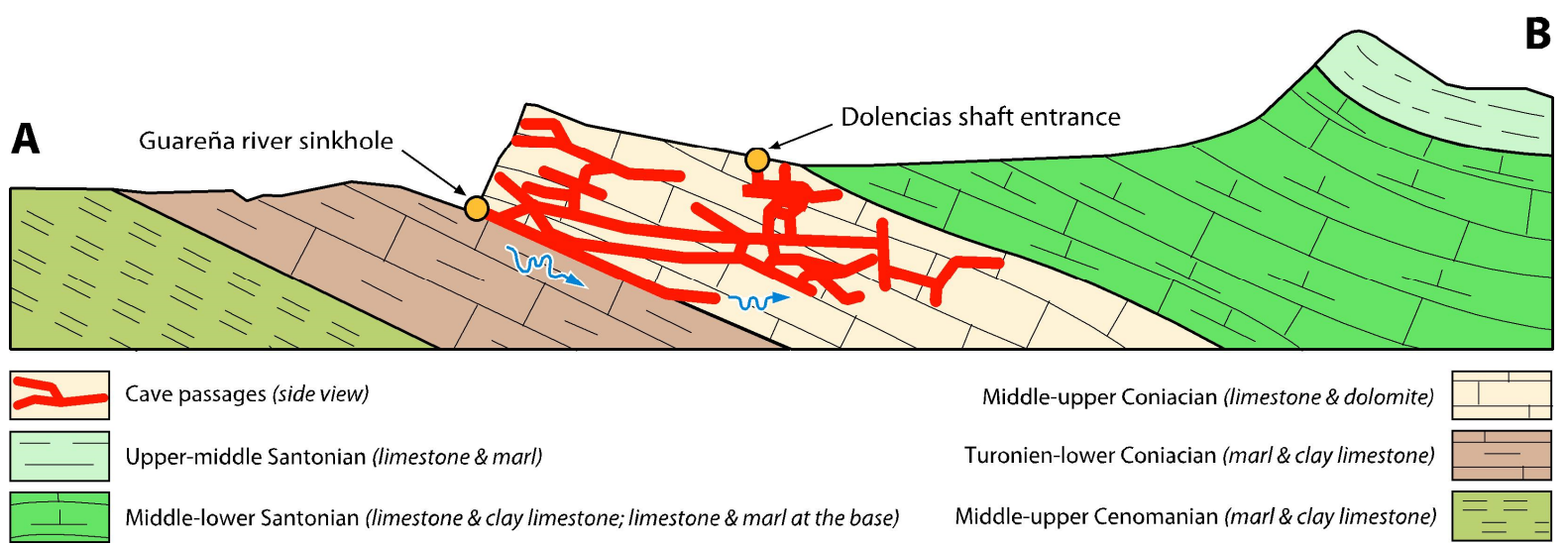

Figure 2. Geological section approximately North-South, corresponding to line A-B in Figure 3. 


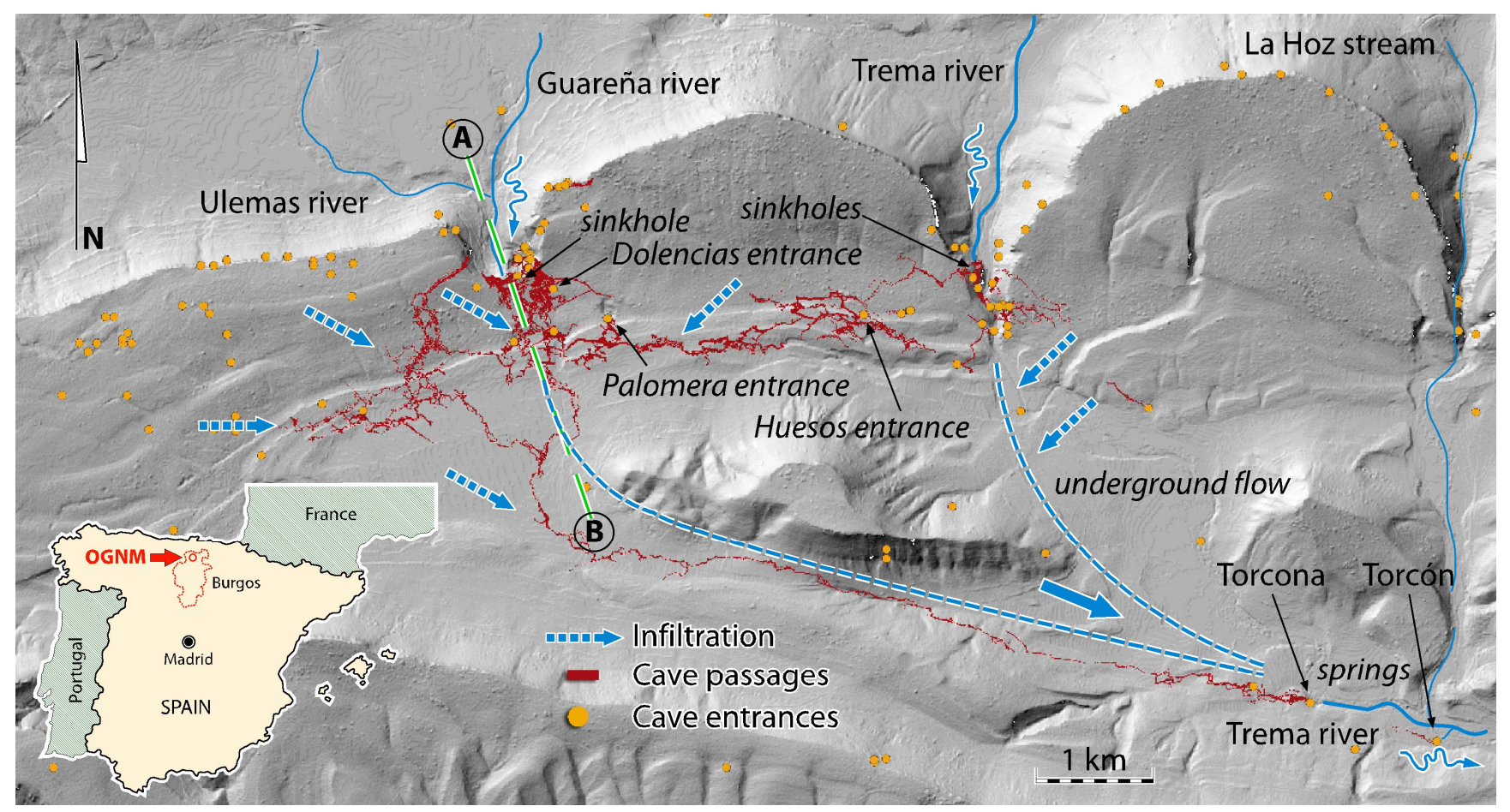

Figure 3. Location of caves, underground galleries, flows, and drainages on a digital elevation model of the OGNM terrain.

The main cave (OG) has 13 entrances: Palomera Cave, Dolencias Shaft, Huesos Shaft, Rizuelos Shaft, Cornejo Cave, Cuatro Pisos Cave, San Bernabé caves, Moro Cave, Trema river sinkholes, La Mina Cave, Guareña river sinkhole (the "Ojo" or Eye), Villallana Cave, and Torcona cave spring (main resurgence of the system) (Table S1) (Figure 3). The last two are connected to the main cave by long flooded passages. The general structure is comprised of a maze of galleries, mainly horizontal, that are arranged along the W-E and $\mathrm{N}-\mathrm{S}$ axes. In the western part of the cave, the galleries are mainly oriented in a NE-SW direction. Other caves of the system that are not yet connected to the main cave include Kubía (surveyed length 550 m), Último Sumidero (350 m), Prado Vargas (130 m), Kaite (585 m), Covanería $(320 \mathrm{~m})$, and Jaime $(650 \mathrm{~m})$. A little further away from the main cave lies Las Yeguas Cave (1900 m). In 1981, the Trema river sinkholes (on the right bank of the river) and La Mina Cave (on the left bank) became connected through two conduits that traverse underneath the bottom of the Trema river canyon. The hypogeal course of this river is only known in the space between two sumps (300 m). In Cornejo Cave, the progression of the underground stream stops in a semi-flooded squeeze.

In short, the current ensemble of galleries developed in a $15 \mathrm{~km}^{2}$ area (Figure 3). Of these, $30 \mathrm{~km}$ are concentrated in an area of just $1 \mathrm{~km}^{2}$, underneath Alto de San Bernabé Hill, just above and to the south of the Guareña river sinkhole. The galleries are distributed in six largely overlapping levels, creating a three-dimensional maze known as "the West Daedalus". The upper levels are almost clogged inactive passages. The intermediate ones present a seasonal hydrological activity that can be very important, depending on the weather. The lower levels are the permanent beds of the Guareña and Trema rivers, to the north and west, respectively, and of Villamartín Stream, to the northwest, feeding a large underground aquifer installed around the axis of the syncline. After a long, partially known path, these water sources reappear in La Torcona, a cave near the eastern limit of the massif, and El Torcón, an inaccessible flooded spring. Hydrological recharge occurs by infiltration of rainwater and snowmelt through permeable formations, as well as by feeding from small hillside springs and by karst sinks that induce flow losses along epigeal channels. The most spectacular cases of recharging in the entire unit are found at the Guareña river sinkhole, at the base of the San Bernabé escarpment, through a penetrable sinkhole ("el Ojo"), and at the Trema river sinkhole in its own channel, shortly before the 
village of Cornejo. The entire endorheic basin represents an area of about $27 \mathrm{~km}^{2}$. After a relatively rapid underground flow $(1.5 \mathrm{~km} /$ day in low water conditions and 4 to $5 \mathrm{~km} /$ day in flooding), the flow drains towards the Trema River, on the southeastern limit of the karst. Although much is known about the behavior of the underground waters that come from the Guareña River, very little is known about those that come from the Trema River.

\subsection{Sampling and Studies of the Fauna}

As mentioned above, the OGNM was only occasionally sampled prior to the first decade of the twenty-first century, when the most intensive and systematic samplings, to date, occurred. The taxa lists compiled here are derived from previous studies of the material obtained from all known samplings, though with a bias towards the more recent ones. Below, we briefly mention some of the sampling techniques used, as well as the extent of sampling.

\subsubsection{Samples of Aquatic Fauna}

Although we do not know the number or specific locations of the samples collected or the specific sampling techniques used by Ortiz during his exploration of the cave, we do have detailed information on the systematic samplings carried out during this century. Between 2002 and 2009, 344 samples of aquatic fauna were collected at OGNM [31]. Sampling was carried out in the main cave (OG), plus 12 other caves and 12 springs, and in the hyporheic environments of the epigean rivers (Table S1):

(a) Main Cave (OG), about $3 \mathrm{~km}$ of main gallery (Palomera to Museo de Cera). A total of 59 sites were sampled (see Table S1 for site names): OG01 to OG16, periodically sampled (methods described below), and OG17 to OG59, sampled once or twice using hand nets (Figure 4). A total of 244 samples was studied.

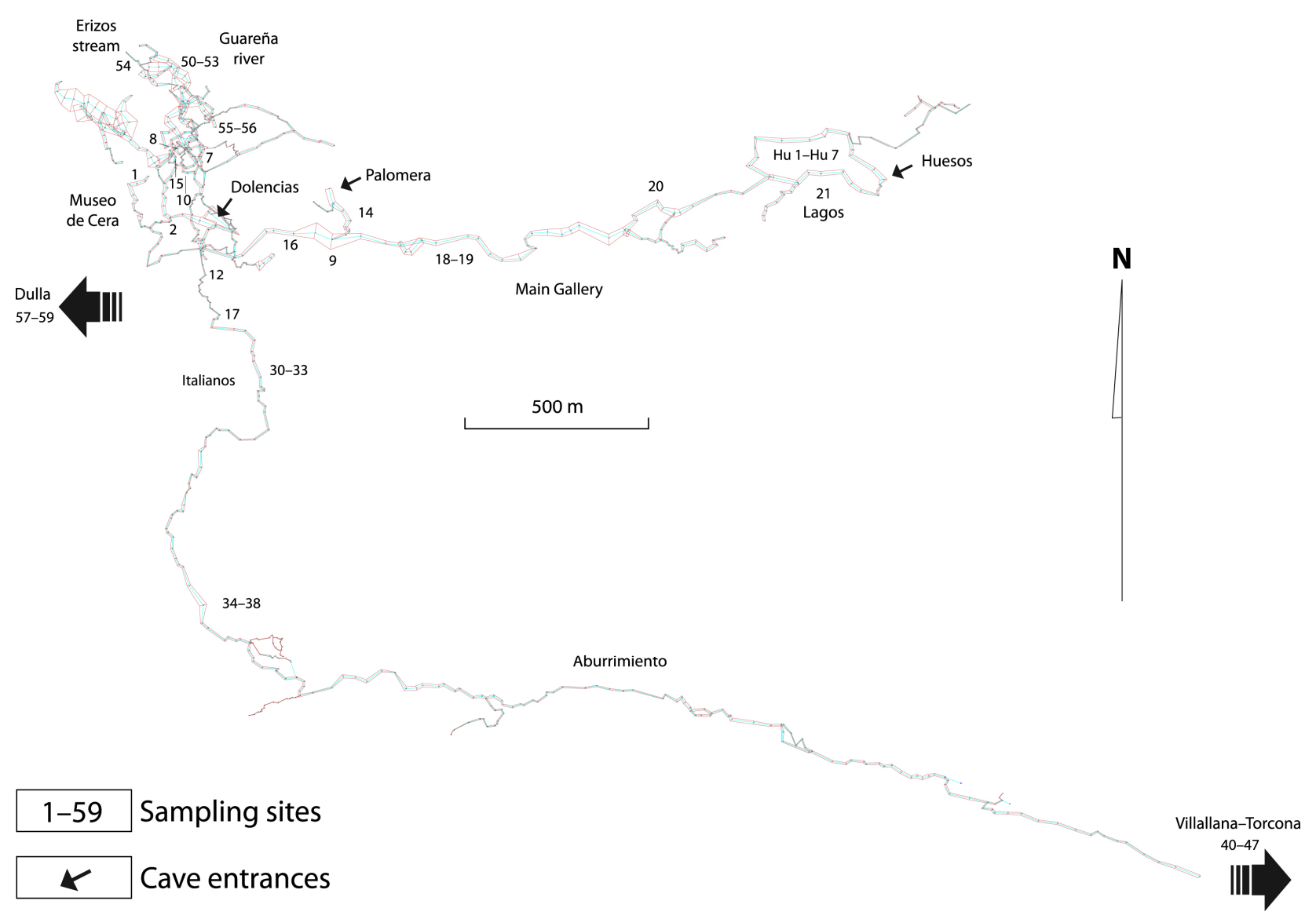

Figure 4. Part of the survey of the main cave, indicating the sampling sites. 
(b) Other caves in the system that were sampled on one or two occasions: Rizuelos, Kaite 2, Jaime, La Mina, Prado Vargas, García, San Bernabé, San Miguel river sinkhole, Las Llanas, Cornejo, Racino, and Redonda. A total of 31 samples were studied.

(c) Springs sampled only once: Torcona, Pozo del Infierno, Cornejo, La Mea, Villa, Salce, Cubío, La Calzada, Jordana, Avellanos, Mazo 1, and Mazo 2. A total of 24 samples were studied.

(d) Hyporheic and interstitial environments of the surrounding rivers and streams that are part of the OGNM aquifer, sampled on one or two occasions and at various points: Guareña, Ulemas, Trema, Trueba, Engaña, Nela, and La Hoz. A total of 43 samples were studied.

(e) Wells sampled only once: Torcón and Villabascones. Only two samples were studied.

Most samplings were restricted to the epikarstic zone of the caves [31]. However, sampling also occurred in some other areas including a couple of underground rivers in the main cave (Erizos and Guareña), the phreatic zone in Aburrimiento gallery (a long southernmost passage), and the resurgences of La Torcona and Villallana.

Eight sampling methods were used [33,34]: (1) traps with bait in free water (ponds and gours) and located within the substrate on riverbanks; (2) direct captures with a manual aspirator; (3) drip collection; (4) the Karaman-Chappuis method (on sandy shores of underground pools and epi- and hypogeal rivers); (5) removing the substrate and filtering the water with a hand net (ponds, gours, potholes) (Figure 5); (6) Bou-Rouch pumping (in La Torcona and in epigean rivers); (7) kicking (in the benthos of the Guareña and Erizos river streams); and (8) Cvetkov nets or other types of phreatobiological nets (in deep lakes and wells). All sampling nets ( $0.100 \mathrm{~mm}$ mesh size) were designed ad-hoc in order to adapt them for the different habitats and types of fauna studied. With the mesh size used, most adult forms of crustaceans and interstitial fauna can be collected.

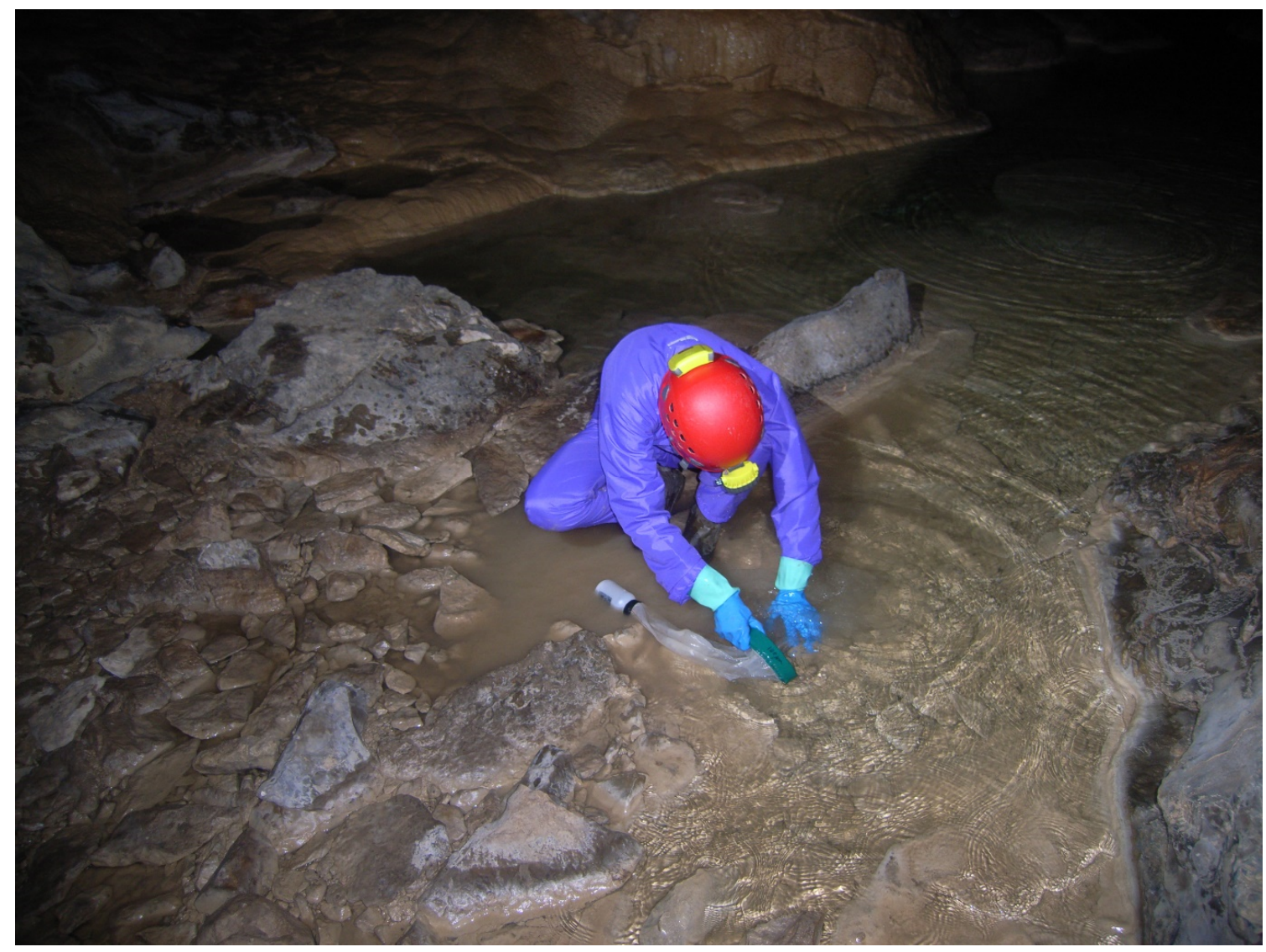

Figure 5. Sampling in "Sala Edelweiss" OG09. Photo C. Puch. 
The samples collected between 2002 and 2004 and between 2007 and 2009 were processed in the MNCN laboratories in Madrid under the supervision of A.I. Camacho [31]. As a great deal of the material collected (mainly ostracods, amphipods and copepods) are still being studied and identified by specialists, some of the entries on the stygobiotic species list have only been identified to the family or genus level. In most cases, samples were identified using classical (morphological) taxonomic methods. For samples of Bathynellacea, molecular analyses of nuclear (18S) and mitochondrial (COI) gene fragments were also carried out for taxonomic purposes. For this, we used DNA extraction and PCR amplification techniques previously developed for this type of fauna $[10,35,36]$.

\subsubsection{Samples of Terrestrial Fauna}

The sampling techniques used in the earlier sporadic sampling visits to the cave are not known. We assume that most samplings were made de visu, a low yield technique, hence the scarcity of available material and data on the few troglobiotic species known at that time. From 2002 to 2004, samples of terrestrial fauna were collected using three techniques:

(1) Baited traps, after being set, were collected periodically (30, 60, 90, and 120 days after setting) in four selected spots in OG, along the main route from Palomera to Museo de Cera, over a distance of about $3 \mathrm{~km}$. Samples collected outside the main cave (OG), from the access doline to the Palomera entrance, [29] were also included in the study.

(2) Sediment samples were collected at four locations in OG at six time points throughout the year, in an attempt to collect cave-dwelling fauna that are not attracted to the baited traps. Sediment samples of the access doline to Palomera, taken over four occasions, were also processed.

(3) Manual aspirators were used to capture samples de visu on every visit to OG.

The collected material was processed in the laboratories of the Department of Animal Biology I of the Faculty of Biology at the Complutense University of Madrid, under the supervision of Pérez-Zaballos [30]. Fauna were extracted from the sediment using the Berlese technique, and taxa were separated into individual groups. In a few cases, specimens could be identified only to the order or family level, and most specimens remain under study by taxonomists specializing in the different terrestrial groups. Some of the material has been deposited in the collections housed at the MNCN (Madrid, Spain).

\section{Results}

Overall, only partial results have been obtained from the samplings: most of the material collected, particularly the terrestrial specimens, are still under study, with their identification to a specific level still pending.

A total of 299 taxa has been identified in OGNM (Table 1), of which 112 are terrestrial and 187 are aquatic [30,31]. A total of 54 of these taxa constitutes subterranean fauna: 46 stygobiotics and 8 troglobiotics. However, another 48 taxa comprising 34 stygophilics and 14 troglophilics (Table S2) were also identified. In many cases, the ecological status of cave animals is difficult to determine [37] and therefore we feel their inclusion is warranted. In the future, the surface/subterranean status of some of these species could change as more information about their ecology and biology comes to light.

Table 1. Number of taxa known in the Ojo Guareña Natural Monument.

\begin{tabular}{cccccc}
\hline TAXA & Total Species & Stygobiotic & Troglobiotic & Stygophilic & Troglophilic \\
\hline & Aquatic/Terrestrial & Species & Species & Species & Species \\
\hline Rotifera & $1 /-$ & 0 & - & - & - \\
\hline Cnidaria & $1 /-$ & 0 & 0 & 0 & - \\
\hline Nematoda & $1 / ?$ & 0 & - & 0 & 0 \\
\hline Turbellaria & $5 /-$ & 0 & - & 1 & - \\
\hline Hirudinea & $3 /-$ & & & - \\
\hline
\end{tabular}


Table 1. Cont.

\begin{tabular}{|c|c|c|c|c|c|}
\hline TAXA & Total Species & Stygobiotic & Troglobiotic & Stygophilic & Troglophilic \\
\hline & Aquatic/Terrestrial & Species & Species & Species & Species \\
\hline Tardigrada & $13 / 3$ & 0 & 0 & 0 & 0 \\
\hline Oligochaeta & $49 / 9$ & 5 & 2 & 8 & 0 \\
\hline \multicolumn{6}{|l|}{ Mollusca } \\
\hline Gastropoda & $11 / 4$ & 2 & 1 & 1 & 0 \\
\hline Bivalvia & $5 / 0$ & 0 & - & 0 & - \\
\hline \multicolumn{6}{|l|}{ Crustacea } \\
\hline Cladocera & $1 / 0$ & 0 & - & 0 & - \\
\hline Ostracoda & $22 / 0$ & 8 & - & 9 & - \\
\hline Copepoda & $37 / 0$ & 9 & - & 12 & - \\
\hline Amphipoda & $8 / 0$ & 4 & - & 0 & - \\
\hline Isopoda & $3 / 1$ & 2 & 0 & 1 & 1 \\
\hline Bathynellacea & $7 / 0$ & 7 & - & - & - \\
\hline Limnohalacarida & $1 /-$ & 1 & - & 0 & - \\
\hline Hydrachnidia & $19 /-$ & 8 & - & 1 & - \\
\hline Oribatida & $-/ 54$ & - & 0 & - & 5 \\
\hline Araneae & $-/ 1$ & - & 0 & - & 1 \\
\hline Opiliones & $-/ 2$ & - & 0 & - & 1 \\
\hline Pseudoscorpioni & $-/ 1$ & - & 0 & - & 1 \\
\hline Myriapoda & $-/ 3$ & - & $\begin{array}{c}1 \\
\text { Chilopoda }\end{array}$ & - & $\begin{array}{c}2 \\
\text { Diplopoda }\end{array}$ \\
\hline Collembola & $-/ 1$ & - & 1 & - & 0 \\
\hline Diplura & $-/ 2$ & - & 1 & - & 0 \\
\hline Zygentoma & $-/ 1$ & - & 0 & - & 0 \\
\hline Coleoptera & $-/ 13$ & - & 2 & - & 3 \\
\hline Diptera & —/12 (Families) & - & 0 & - & 0 \\
\hline Hemiptera & —/1 (Order level) & - & 0 & - & 0 \\
\hline Lepidoptera & -/1 (Order level) & - & 0 & - & 0 \\
\hline Orthoptera & -/1 (Order level) & - & 0 & - & 0 \\
\hline Psocoptera & -/1 (Order level) & - & 0 & - & 0 \\
\hline Psiphonaptera & -/1 (Order level) & - & 0 & - & 0 \\
\hline TOTAL: 299 & 187/112 & 46 & 8 & 34 & 14 \\
\hline
\end{tabular}

\subsection{Aquatic Fauna}

Table 1 shows the distribution of the 187 aquatic taxa in OGNM by faunal group. Crustacea is the largest group, with 78 species, 30 of which are stygobiotics (some without a specific name). Groups with the largest species numbers include Copepoda, Ostracoda and Bathynellacea. Only five of the 49 aquatic species of Oligochaeta are stygobionts. In the case of the Acari, nine of the 20 aquatic species are stygobiotics. The two remaining stygobiotics species are Mollusca (two gastropod species). Similar to the case of the stygobiotics, most of the 34 stygophilic species belong to the Copepoda (12 species), Ostracoda (9), and Oligochaeta (8) (Table 1). 
Although this work focuses on the subterranean species present in OGNM, it is important to highlight the repeated presence of the up to 187 taxa in the samples, and their unequal distributions and abundances among the different subterranean aquatic habitats and sampling points. As an important energetic resource of the ecosystem, this aquatic fauna may be able to provide information on the diversity and disparity of populations in different localities [31].

Below, we provide a list of stygobiont taxa found in OGNM. All of the samples have been reviewed by expert taxonomists; thus, we consider the list as valid, without specifying whether the "sp." notation refers to a new species, an already known species, or, possibly, a cryptic species. The specific site(s) from which each taxa was collected in OGNM is also included.

List of stygobiont species found in the Ojo Guareña National Monument, and their specific sites (sampling sites in the main cave, through the Palomera entrance: OG01-OG59, Figure 4).

Oligochaeta

Gianius navarroi Rodriguez and Achurra, 2010. OG10 and OG14.

Delaya navarrensis (Delay, 1973). OG21.

Stylodrilus mariae Achurra, Rodriguez and Erséus, 2015. OG07 and OG08.

Trichodrilus tenuis Habre, 1960. OG14.

Trichodrilus sp. 1. OG09.

Mollusca

Palaospeum septentrionale (Rolan and Ramos, 1995). Sima Jaime Cave, De la Hoz Creek, and Torcona Spring.

Spiralix (Burgosia) burgensis Boeters, 2003. Sima Jaime Cave, Trema River, and Trueba River.

Hydrachnidia

Axonopsis (Paraxonopsis) vietsi Motas and Tanasachi, 1947. Trueba River.

Frontipodopsis reticulatifrons Szalay, 1945. OG08, OG10, and Engaña River.

Frontipodopsis sp. Lasía River.

Kongsbergia sp. Trueba and Lasía rivers.

Neoacarus hibernicus Halbert, 1944. Nela River.

Protzia sp. Trueba River.

Pseudotorrenticola sp. Nela River.

Sperchonopsis sp. Lasía River.

Limnohalacarida (Halacaridae)

Soldanellonyx chappuisi Walter, 1917. OG: 07-10, 12, 14, 15, 17, 19, 30, 31, 34, 36-38, and 50; caves: Rizuelos, García, San Miguel, Cornejo and Redonda; springs: Torcona and Calzada; rivers: Trema, Trueba, Engaña, Nela, and De la Hoz and Torcon Well.

Copepoda, Cyclopoida

Acanthocyclops cf. venustus (Norman and Scott, 1906). Engaña and Nela rivers.

Acanthocyclops n. sp. OG: 10, 31, 34, 37, and 38 .

Graeteriella (G.) unisetigera (Graeter, 1910). OG02 and OG07.

Speocyclops infernus (Kiefer, 1930). OG: 01, 08, 09, 14, 16-19, 21, 31, 38, and Huesos 2 and 4 .

Speocyclops sebastianus Kiefer, 1937. Trema River.

Speocyclops spelaeus Kiefer, 1937. Caves: García, San Bernabé, Las Llanas, and Racino.

Copepoda, Harpacticoida

Bryocamptus (Rheocamptus) pyrenaicus (Chappuis, 1923). Caves: Kaite 2, García, Cornejo, Racino, and Redonda; Salce Spring.

Paracamptus sp. SA. Nela River.

Parastenocaris sp. OG: 07-09, 12, 14, 16, 17, 20, 21, 31-38, 41-43, 45, 46, 51-54, and

Huesos 2; Villa Spring and De la Hoz and De la Cueva creeks. 


\section{Ostracoda}

Candoninae cf. gen. sp. 1 "Rounded". OG: 07, 09, 12, 17, 19, 21, 39; spring: Torcona, Cornejo and Calzada; Nela River.

Candoninae "Trapezoid" 1. OG: 09, 19, 21; caves: Jaime, La Mina, Las Llanas; Guareña River.

Candoninae cf. gen. sp. 2 "Trapezoid" 2. OG09.

Candoninae cf. gen. sp. 2 "Trapezoid" 3. OG: 1, 18, 37, 38.

Candoninae "Triangular" 1. OG: 15, 30-32 and Trema River.

Candoninae "Triangular" 2. OG16 and Sima Jaime Cave.

Candoninae "Triangular" 3. Torcona Spring and Trema River.

Cypria sp. OG: 7, 9, 10, 35, 40, 42, 43, 51, 55-59, Huesos 2 and 3; San Miguel Cave; springs: Cornejo, Villa, Salce, Cubio, and Jordana; rivers: Guareña and Lasía.

Amphipoda

Haploginglymus sp. 1. OG38; Torcona Spring; river: Trema, Trueba, and Nela; Torcon well.

Niphargus sp. OG37 and 38; Cubio Spring and Trueba River.

Pseudoniphargus burgensis Notenboom, 1986. Torcona Spring.

Pseudoniphargus n. sp. 1. Torcona Spring.

Isopoda

Cantabroniscus primitivus Vandel, 1965. OG21.

Stenasellus virei buchneri (Stammer, 1936). OG: 02, 07, 09, 10, 14, 15, 17, 21, 39, 40, 44, 53, 55, and 57; caves: García, San Bernabé, San Miguel, Las Llanas, and Redonda and Salce Spring.

Bathynellacea

Iberobathynella burgalensis Camacho, 2005. OG53.

Iberobathynella cornejoensis Camacho, 2005. Redonda and Racino caves and Trema River. Iberobathynella guarenensis Camacho, 2003. OG57 ("Erizos River").

Vejdovskybathynella edelweiss Camacho, 2007. OG01, 09, 16, 17, 38, 50, 57, and Huesos 3 and 4; Racino and Mina caves and Cubio Spring

Vejdovskybathynella n. sp. 1 (cryptic species "edelweiss"). OG57 ("Erizos River").

Vejdovskybathynella n. sp. 2 (cryptic species "edelweiss"). Redonda and Sima Jaime caves.

Bathynellidae n. gen. n. sp. OG09, 14, Torcona Spring and Prado Vargas Cave.

In OG, 25 stygobiotic species have been found across the 59 sampling sites, with many of the species being found in OG09 (12 species), followed by OG07, OG08, and OG10 (11 species each) and OG14 (seven species) (Figure 4).

Of the five stygobiotic species of Oligochaeta found in OG, Gianius navarroi described from OG [38], has only been found in two small ponds, OG10 and OG14. The two species of Mollusca live in other caves, springs and rivers but not in OG. The eight stygobiotics of Hydrachnidia live in the rivers, though one, Frontipodopsis reticulatifrons, has also been found in OG8 and OG10, two small epikarstic ponds that are filled with water from diffuse drips. The stygobiotic species of Limnohalacaridae is widely distributed throughout the principal cave (in many of the sites), and in all of the other types of habitats (multiple springs and rivers, and one of the two wells).

Crustaceans, a major animal group found in groundwater worldwide [2], are very well represented in OGNM by 78 taxa, 30 of which are stygobionts (Table 1). Copepods are present in almost all ponds and pools in OG. Of the 37 copepod species found, nine are stygobiotics that live in several caves and rivers and in a couple of springs. Twentytwo identified species of ostracods are distributed around OGNM. Of these, eight are stygobiotics that inhabit all the different types of sites sampled. Species of three of the five genera of Amphipoda found at the system are stigobiotics. They live mainly in springs and rivers, and also in two sites of OG. Of the two stygobiotic isopod species 
found, Cantabroniscus primitivus has only been found in the "siete lagos" area (OG21). The other species, Stenasellus virei buchneri (Figure 1), has been found in many sites in OG and in some of the other caves and springs. In addition to these isopod species, we found Proasellus cf ortizi, (Table S2), which we conservatively consider a stygophilic, despite its cave-like morphology. This species has been consistently found in OG12, although at varying abundances, and in three springs (Avellanos, Mea, and Jordana).

Bathynellacea, a strictly stygobiotic group of crustaceans, is represented in OGNM by seven species belonging to two families: Parabathynellidae and Bathynellidae (Figures 6 and 7). Four of the species, three belonging to Parabathynellidae (Iberobathynella Schminke, 1973 genus) and one to Bathynellidae (Vejdovskybathynella Serban and Leclerc, 1984 genus), have already been formally described [12-14,39]. The second genus found belonging to Bathynelidae is pending description. On the basis of molecular data, we discovered two cryptic species of Vejdouskybathynella within the family Bathynellidae [40]. These species are currently under further study. To our knowledge, no other karst area in the world has as many known species of Bathynellacea living together. The specimens of Bathynellidae found in Erizos River and Redonda Cave were initially identified as Vejdovskybathynella edelweiss (Figure 6), which is known from seven sites in OG, and from other caves of the system (Huesos, Racino, La Mina, and Cubio Spring). It is the most widely distributed species in OGNM. However, the specimens from Erizos River show a genetic divergence in the COI gene of $14.8 \%$ with the nominal species, and $17 \%$ with the specimens from Redonda Cave, which, in turn, show a $15.2 \%$ divergence with the nominal species [40]. These results imply that the specimens from Erizos and from Redonda each constitute a distinct species, and that there are actually three morphologically similar species of Vejdovskybathynella in the sampled sites. We expect this case will not be an isolated event, suggesting the biodiversity of the system is far greater than has been estimated. The distribution of the bathynellaceans is patchy. Species of both families have been found together in Redonda Cave and Erizos River (the only site from which I. guarenensis has been described). Vejdovskybathynella edelweiss and the new genus coexist in OG09. Iberobathynella burgalensis (Figure 7) only lives in gours in OG53. Iberobathynella cornejoensis, which has not been found in the main cave, inhabits a couple of small caves of the complex including Redonda (near the Trema sinkholes, where it has also been found) and Racino (to the west).

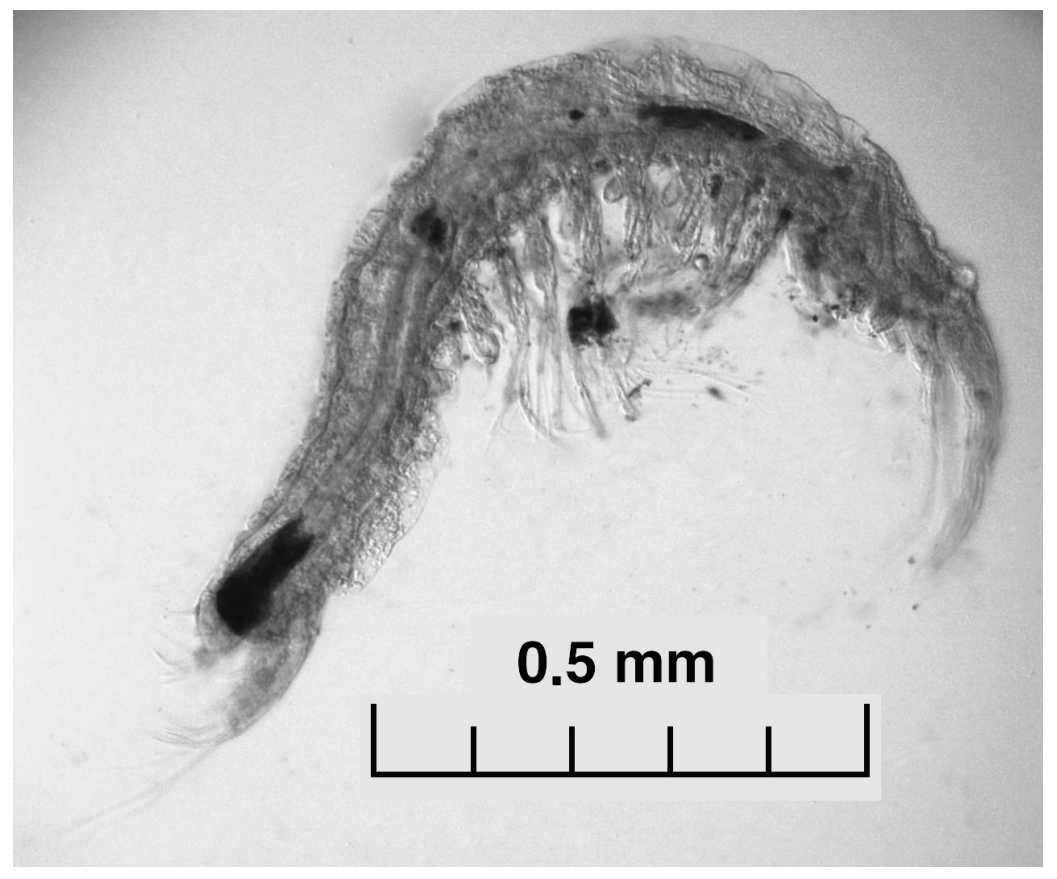

Figure 6. Habitus of Vejdovskybathynella edelweiss Camacho, 2007. 


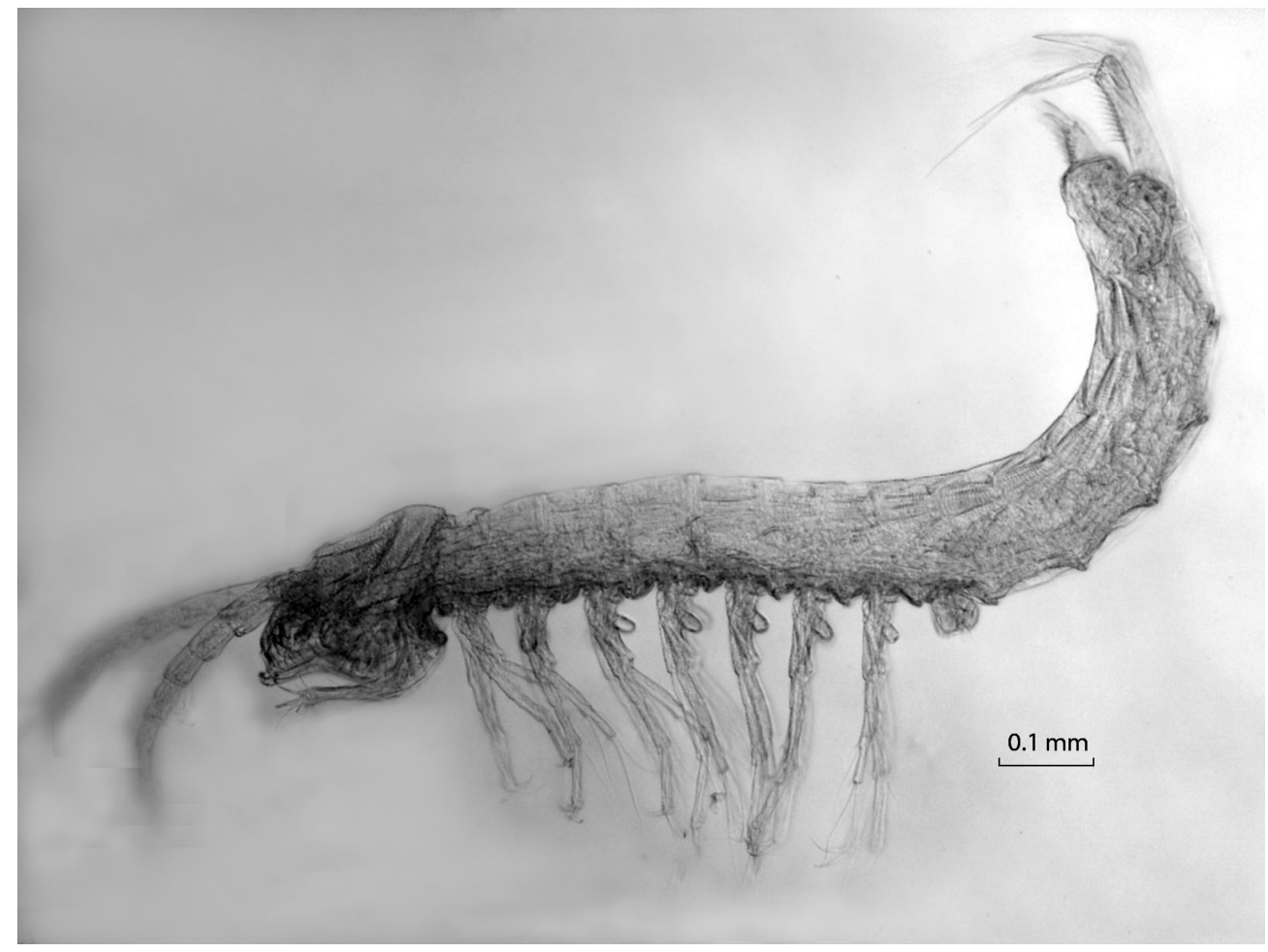

Figure 7. Habitus of Iberobathynella burgalensis Camacho, 2005.

\subsection{Terrestrial Fauna}

The terrestrial fauna in OGNM is poor compared with those in other systems: only 8 troglobiotic and 14 troglophilic species have been identified (Table S2). This is more likely due to a lack of sampling and study rather than to an absence of species. Given that we still have some samples waiting to be identified to the species level, we expect this number to increase.

Between 1968 and 1975, Ortiz sampled the terrestrial and aquatic fauna in Palomera. The material collected from two clayey areas of Palomera and from zones with organic residues throughout OG were subsequently studied by specialists [22-25] and gave rise to two monographs, one on terrestrial oligochaetes (eight species but only two troglobionts) [41] and another on oribatid mites (43 species but no troglobionts; three were new to Spain, and two were new to science) [42].

Other previous studies of terrestrial fauna in OG include those by Bellés and Antón [18]; Prieto and Gómez [43], who studied some terrestrial molluscs collected by the Niphargus Cave Club. Demange and Serra [44] described the only myriapod known from OG. Rambla cites the presence of a troglobiont opilion in OG [45] that Prieto and Zubiaga later studied [46]. Español [47] studied 10 coleopterans collected by Ortiz and found six species, one of them new to science (Trechus ortizi). The presence of some of these species in OG were confirmed through the samplings carried out between 2002 and 2003; however, most of the specimens from these later campaigns have yet to be identified by specialists.

The list of well-identified troglobiotic species is short, and specific information on the sites in which they have been found is lacking.

List of troglobiotic species found in the main cave of the Ojo Guareña National Monument: Oligochaeta:

Aporrectodea rosea troglodyta (Álvarez, 1971).

Orodrilus paradoxoides (Álvarez, 1971).

Mollusca:

Zospeum schaufussi Frauenfeld, 1862. 
Arachnida, Opiliones:

Litocampa zaldivarae Sendra, Salgado and Monedero, 2003.

Myriapoda, Chilopoda:

Lithobius deroutae sexusbispiniger Demange and Serra, 1978.

Collembola:

Verhoeffiella cf hispanicus (Bonet, 1931).

Coleoptera:

Speocharis sharpi Escalera, 1898.

Trechus ortizi Español, 1970.

\section{Discussion and Conclusions}

Only a small fraction of the terrestrial ecosystem of OGNM has been studied: knowledge of the species that occur in the complex stems from sporadic samplings conducted during the second half of the twentieth century and between 2002 and 2003, with many of the specimens collected still unstudied. Therefore, a few data available about the troglobiotic fauna in the system makes any discussion irrelevant. By contrast, the abundance of information on the subterranean aquatic fauna of OGNM makes their discussion important, despite the fact that only a small part of the system's aquatic environment has been studied. Over a total of six years (2002-2004 and 2006-2009), a series of selected sites from the epikarst of the main gallery had been regularly sampled, with many other areas of the vast subterranean territory sporadically sampled.

The information available for the stygofauna goes beyond that provided by a still photo taken during sampling. Repeated samplings at different times of the annual cycle and over successive years (thus considering changes in environmental conditions or variability of drought-flood cycles) are necessary to find a stygofauna that is formed, in general, by "rare" species (i.e., those that are scarce or difficult to locate) that live in small populations in places with little to no access.

The obtained data reveal the typical patchy distribution of subterranean aquatic fauna [48]. The great heterogeneity of microhabitats, in a highly connected, vast continuous karstic extension, could explain the high richness of subterranean species observed in OGNM, as has been demonstrated in other cases $[49,50]$. Habitat heterogeneity and the spatiotemporal dynamics of this subterranean aquatic ecosystem are also evidenced by the great variation of species and communities observed, even over short periods of time and at a local scale of a few meters [31], a result common for subterranean environments [51-53].

Despite numerous samplings, covering the different microhabitats (gours, drips, ponds, lakes, and the interstitial medium of hypogean streams), large sections of OGNM remain unexplored, from both a topological (e.g., permanently flooded sections) and biological perspective. The inability to sample the entirety of the karst system implies an underestimation of its species richness.

The subterranean aquatic fauna in most karst areas in Europe has been fairly well studied, with around 1800 stygobiotic species known to date [54]. In Spain, slightly more than 200 are known from very few areas (representing 11\% of all known species in Europe) [11]. In OGNM, of the 187 aquatic taxa found (see Table 1), 46 are stygobiotics, accounting for almost a quarter of all stygobiotic species known in our country. However, many of these taxa have been identified to only the genus level (e.g., for some taxa of Oligochaeta, Copepoda, Amphipoda, and Acari), or the subfamily level (e.g., Candoninae (Ostracoda)), and many specimens remain unidentified, suggesting the number of stygobiotic species will likely increase as more studies are published. We do not yet know the extent of endemism or the number of new species in OGNM, as many specimens from all of the major groups remain under study and have not yet been identified to a specific level.

Crustaceans constitute a major animal group in groundwater [2]: around 3400 species are known worldwide, 1200 of which are known to occur in Europe [54]. We identified 30 stygobiotic crustacean species in OGNM. Remarkably, we found seven species of 
Bathynellacea in OGNM. This is a unique case as in no other karst system has this many species been found in coexistence. Moreover, the seven species are distributed among three genera: two known ones (Iberobathynella Schminke, 1973, and Vejdovskybathynella Serban and Leclerc, 1984, each with three species) and a third (Bathynellidae n. gen. $n$. sp.) that is new to science. Specimens of these species have been found, within the main cave, in five pools and the Erizos River, and in five of the other caves, two springs, and the Trema River. The two cryptic species of Vejdovskybathynella, Vejdovskybathynella sp. 1 and Vejdorskybathynella sp. 2, have also been found in two nearby caves outside OGNM, Río Chico, and Imunía [55]. The other five species of Bathynellacea are endemic to OGNM. A possible scenario is that the ancestral populations of these species, which were likely widely distributed in the area, became isolated due to droughts and vicariance. Although Bathynellacea lack active forms of dispersal (they do not have swimming larvae, like other crustaceans) and are generally not very mobile, a later (passive) dispersal event may have led to their genetic isolation and consequent speciation, resulting in the unusually high number of species coexisting, though in a patchy way, in a relatively small area. However, phylogeographic studies of these species are needed to confirm any of these hypotheses.

The largest number of stygobiotic species found in OGNM occur in the main cave (OG), with 25 species. A large number of these species is found at several sites: 12 species in OG09; 11 in OG07, OG08, and OG10; and seven in OG14. In addition, in general, the species were repeatedly found in all samplings, although in different proportions [31]. The 25 stygobiotics, along with the seven known troglobiotics, make OG a subterranean biodiversity hotspot within the wider OGNM hotspot (with its 54 subterranean species).

The number of stygobiont species in OGMN is striking. In no other area of Spain and Portugal has such a level of subterranean biodiversity been reported (see Table 1), even in the four hotspot caves in the Canary Islands (Felipe Reventón, Viento, Sobrado, and La Corona lava tube), which have between 28 and 36 troglobiotic species the first three and 38 stygobiotic species La Corona [2,3].

To improve our knowledge of the diversity of a region, it is essential to have large inventories of well-identified, georeferenced species in order to conduct standardized geospatial analyses that can be compared among regions and at different spatial scales $[2,56]$. Although the available data clearly demonstrate that the subterranean biodiversity in OGNM is relatively high, especially compared with that of other caves in the world [57,58]. The balance of sites and specific samples studied shows the relevance that the small known fraction can have compared with all that remains to be explored and studied from a biological perspective.

Among the common shortfalls of biodiversity data, the "Racovitzan impediment" is of great importance in the case of the OGNM. The sampling deficiency is large: there are numerous habitats not directly accessible to humans that, therefore, have not been sampled to date. Thus, we lack information about the species they may harbor. In addition, the lag between sampling efforts and the taxonomic identification of all specimens makes it difficult to obtain accurate data on the overall biodiversity of the system and its distribution. Although we are likely underestimating the real diversity of subterranean fauna in OGNM due to these issues, we confirm the prediction made by Culver and Pipan [2]: a subterranean hotspot is indeed present in northern Spain. Here, we provide the first list of stygobiotic and troglobiotic taxa present in OGNM, as well as demonstrate that, despite some knowledge gaps, this complex is a hotspot of subterranean biodiversity. Moreover, the diversity observed to date for OGNM implies its high rank among hotspot caves in not only Europe, but the world.

Future lines of research should focus on resolving the ecological status of the 48 taxa provisionally considered as stygophilics (34) or troglophilics (14) (see Table S2); discovering potential new cryptic species among the fauna through molecular analyses, such as those used to reveal cryptic species in the families Bathynellidae [55] and Parabathynellidae [59]; and identifying all remaining material to the lowest taxonomic level possible. These studies, 
along with a greater sampling effort, will all contribute to increase our knowledge of the subterranean biodiversity of this exceptionally conserved karst ecosystem.

Supplementary Materials: The following materials are available online at https://www.mdpi. com/article/10.3390/d13050199/s1: Figure S1, Stenasellus virei buchneri (Stammer, 1936) in OG14; Table S1, Georeferenced list of sampled sites on the Ojo Guareña Natural Monument; Table S2, List of stygophile and troglophile species and the sites where they have been found in Ojo Guareña Natural Monument.

Author Contributions: Both authors participated in all phases of the realization and writing of the paper. Both authors have read and agreed to the published version of the manuscript.

Funding: This work was supported by project PID2019-110243GB-100 (Ministerio de Ciencia e Innovación/FEDER).

Institutional Review Board Statement: Not applicable.

Informed Consent Statement: Not applicable.

Data Availability Statement: All data are available from the authors upon request.

Acknowledgments: We express our gratitude to J. Fernandez and B. Sanchez-Chillón for reviewing their bibliographic and specimen collections, respectively, for this study. We thank the Spanish PASCALIS team, as well as Fortunato Lázaro, Ana M. de Juan, and Jesús Robador for their participation in the samplings. Thanks to Pilar Rodríguez and Sanda Lepure for reviewing and correcting the list of oligochaetes and copepods, respectively. Thanks also to Consuelo Temiño and Beatriz Cabezas for their help from 2002-2010 under the agreements of the Junta de Castilla y León and the CSIC, and to the MNCN and the CSIC for their support in carrying out this work. And lastly, thanks to Miguel Rioseras for providing us with the surveys and cartographic data and Melinda Modrell, who helped us with the English translations.

Conflicts of Interest: The authors declare no conflict of interest.

\section{References}

1. Puch, C. La Montaña subterránea. Pyrenaica 2009, 235, 331-333.

2. Culver, D.; Pipan, T. Subterranean Ecosystems. In Encyclopedia of Biodiversity, 2nd ed.; Levin, S.A., Ed.; Academic Press: Waltham, MA, USA, 2013; Volume 7, pp. 49-62. [CrossRef]

3. Martínez, A.; González, B.C. Volcanic Anchialine Habitats of Lanzarote. In Cave Ecology; Ecological Studies 235; Moldovan, O.T., Kovác, L., Halse, S., Eds.; Springer: Cham, Switzerland, 2018; pp. 195-228.

4. Puch, C. Grandes Cuevas y Simas de España; Espelo Club de Grácia-Federación Española de Espeleología: Barcelona, Spain, $1998 ;$ p. 816.

5. Culver, D.C.; Deharveng, L.; Bedos, A.; Lewis, J.J.; Madden, M.; Reddell, J.R.; Sket, B.; Trontelj, P.; White, D. The mid-latitude biodiversity ridge in terrestrial cave fauna. Ecography 2006, 29, 120-128. [CrossRef]

6. Gulden, B. Official list of the National Speleological Society (USA). Available online: http://www.caverbob.com/wlong.htm (accessed on 2 February 2021).

7. Camacho, A.I.; Temiño, C.; Cabeza, B.; Puch, C. El Monumento Natural de Ojo Guareña (Burgos, España): Un “hotspot” de biodiversidad acuática subterránea. In Cuevas: Patrimonio, Naturaleza, Cultura y Turismo; Durán, J.J., Carrasco, F., Eds.; Asociación de Cuevas Turísticas Españolas: Madrid, Spain, 2010; pp. 621-636, ISBN 13:978-84-614-4630-8.

8. Wilson, E.O. Biodiversity research requires more boots on the ground. Nat. Ecol. Evol. 2017, 1, 1590-1591. [CrossRef]

9. Ficetola, G.F.; Canedoli, C.; Stoch, F. The Racovitzan impediment and the hidden biodiversity of unexplored environments. Conser. Biol. 2018, 33, 214-216. [CrossRef]

10. Camacho, A.I.; Dorda, B.A.; Rey, I. Undisclosed taxonomic diversity of Bathynellacea (Malacostraca: Syncarida) in the Iberian Peninsula revealed by molecular data. J. Crust. Biol. 2012, 32, 816-826. [CrossRef]

11. Deharveng, L.; Stoch, F.; Gibert, J.; Bedos, A.; Galassi, D.; Zagmajster, M.; Brancelj, A.; Camacho, A.; Fiers, F.; Martin, P.; et al. Groundwater biodiversity in Europe. Freshw. Biol. 2009, 54, 709-726. [CrossRef]

12. Camacho, A.I. Four new species of groundwater crustaceans (Syncarida, Bathynellacea, Parabathynellidae) endemic to the Iberian Peninsula. J. Nat. Hist. 2003, 37, 2885-2907. [CrossRef]

13. Camacho, A.I. One more piece in the genus puzzle: A new species of Iberobathynella Schminke, 1973 (Syncarida, Bathynellacea, Parabathynellidae) from the Iberian Peninsula. Graellsia 2005, 61, 123-133. [CrossRef]

14. Camacho, A.I. The first record of the genus Vejdovskybathynella Serban and Leclerc, 1984 (Syncarida, Bathynellacea, Bathynellidae) in the Iberian Peninsula: Three new species. J. Nat. Hist. 2007, 41, 2817-2841. [CrossRef]

15. Camacho, A.I.; Torres, T.; Puch, C.J.; Ortiz, J.E.; Valdecasas, A.G. Small-scale biogeographical pattern in groundwater Crustacea (Syncarida, Parabathynellidae). Biodivers. Conserv. 2006, 15, 3527-3541. [CrossRef] 
16. Ortega, A.I.; Ruiz, F.; Martín, M.A.; Benito, A.; Vidal, M.; Bermejo, L.; Karampaglidis, T. Prehistoric human tracks in Ojo Guareña Cave System (Burgos, Spain): The Sala and Galerías de las Huellas. In Reading Prehistoric Human Tracks; Pastoor, A., Lenssen-Erz, T., Eds.; Springer: Berlin/Heidelberg, Germany, 2021; pp. 1-21. ISBN 10-3030604055; ISBN 13-978-3030604059.

17. Sáenz, C. Notas acerca de la estratigrafía del Supracretáceo y del Numulítico en la cabecera del Nela y zonas próximas. Bol. $R$. Soc. Esp. Hist. Nat. 1933, XXXIII, 159-185.

18. GEE (Grupo Espeleológico Edelweiss). Monografía sobre Ojo Guareña. Kaite 1986, 4-6, 1-415.

19. Bellés, X. Ptinidos recogidos en cavidades subterráneas ibéricas (Col. Ptinidae). Speleon 1976, 22, $145-147$.

20. Bellés, X. Notas sobre Speocharis minus Jeannel, 1909 y otros catópidos recogidos en cuevas de la provincia de Burgos. Graellsia $1977,31,115-124$.

21. Bellés, X. Nuevos datos sobre la Fauna de Ojo Guareña. Ixiltasun Izkutuak, 1986; Unpublished.

22. Bellés, X. Fauna Cavernícola i Intersticial de la Península Ibérica i les Illes Balears; Monografies Cientifiques, 4; CSIC: Mallorca, Spain, 1987; p. 207.

23. Salgado, J.M. Origenes e distribuçao geográfica des Bathysciinae (Col. Catop.) cantábricos (Grupo Speocharis). Ciénc. Biol. 1976, 1, 105-130.

24. Salgado, J.M. Nuevos datos sobre Entomofauna Cavernícola de la zona de Carranza (Vizcaya). Kobie 1977, 7, 127-138.

25. Vives, E. Coleópteros cavernícolas nuevos o interesantes de la Península Ibérica y Baleares. Speleon 1976, 22, 159-169.

26. Vives, M. Noves localitats de Trichoniscidae cavernicolas de la fauna espanyola (Crustacís: Isopodes: Oniscoides). Com. VI. Simp. Espeleol. Biospeleol. 1977, 97-101.

27. Notenboom, J.; Meijers, I. Investigaciones sobre la fauna de las aguas subterráneas de España: Lista de estaciones y primeros resultados. In Verslagen en Technische Gegevens; Instituut voor Taxonomische Zoölogie (Zoologische Museum), Universiteit von Amsterdam: Amsterdam, The Netherlands, 1985; Volume 42, pp. 1-43.

28. Notenboom, J. Introduction to the Iberian Groundwater amphipods. Limnetica 1990, 6, 165-176.

29. Camacho, A.I. Informe Biológico: Ojo Guareña (Sotoscueva-Burgos), 1993; Unpublished. 29.

30. Camacho, A.I.; Valdecasas, A.G.; Rodríguez, J.; Puch, C. Biodiversidad Faunística del Complejo Kárstico de Ojo Guareña: Evaluación de la Influencia de la Presión Humana en Algunas de Las Poblaciones de Invertebrados en el Monumento Natural de Ojo Guareña (Burgos), Informe Final, Marzo. 2005; Unpublished. 110.

31. Camacho, A.I.; Puch, C. Colonización, éxito Evolutivo y Biodiversidad Faunística del Complejo Kárstico de Ojo Guareña en el Monumento Natural de Ojo Guareña (Burgos), Informe Final. 2010; Unpublished. 240.

32. Olmo, P.d.; Ramírez del Pozo, J. Mapa Geológico 1:50.000 nº 84 (Espinosa de los Monteros); IGME: Madrid, Spain, 1978.

33. Camacho, A.I. Sampling the subterranean biota. Cave (aquatic environment). In The Natural History of Biospeleology; Camacho, A.I., Ed.; Monografías del Museo Nacional de Ciencias Naturales, 7; CSIC: Madrid, Spain, 1992; pp. 135-168. ISBN 84-00-07280-4.

34. Malard, F.; Dole-Olivier, M.J.; Mathieu, J.; Stoch, F.; Brancelj, A.; Camacho, A.I.; Fiers, F.; Galassi, D.; Gibert, J.; Lefebure, T.; et al. Sampling Manual for the Assessment of Regional Groundwater Biodiversity. PASCALIS Project (V Framework Programme. Key Action 2: Global Change, Climate and Biodiversity. 2.2.3 Assessing and Conserving Biodiversity); Malard, F., Ed.; Pascalis: Villeurbanne, France, Contract $\mathrm{n}^{\circ}: \mathrm{N}^{\circ}$ EVK2-CT-2001-00121; 2002; p. 110. Available online: http//www.pascalis-project.org (accessed on 31 March 2021).

35. Camacho, A.I.; Dorda, B.A.; Rey, I. Identifying cryptic speciation across groundwater populations: First COI sequences of Bathynellidae (Crustacea, Syncarida). Graellsia 2011, 67, 7-12. [CrossRef]

36. Camacho, A.I.; Dorda, B.A.; Rey, I. Old and new taxonomic tools: Description of a new genus and two new species of Bathynellidae from Spain with morphological and molecular characters. J. Nat. Hist. 2013, 47, 1393-1420. [CrossRef]

37. Deharveng, L.; Bedos, A. Diversity of terrestrial invertebrates in subterranean habitats. In Cave Ecology; Moldovan, O.T., Kovác, L., Halse, S., Eds.; Springer: Cham, Switzerland, 2018; pp. 107-172.

38. Rodriguez, P.; Achurra, A. New species of aquatic oligochaetes (Annelida: Clitellata) from groundwaters in karstic areas of northern Spain, with taxonomic remarks on Lophochaeta ignota Stolc, 1886. Zootaxa 2010, 2331, 21-29. [CrossRef]

39. Camacho, A.I. Expanding the taxonomic conundrum: Three new species of groundwater crustaceans (Syncarida, Bathynellacea, Parabathynellidae) endemic to the Iberian Peninsula. J. Nat. Hist. 2005, 39, 1819-1838. [CrossRef]

40. Camacho, A.I.; Dorda, B.A.; Rey, I. Integrating DNA and morphological taxonomy to describe a new species of the family Bathynellidae (Crustacea, Syncarida) from Spain. Graellsia 2013, 69, 179-200. [CrossRef]

41. Álvarez, J. Biospeleología de la cueva Ojo Guareña. Oligoquetos terrícolas. Bol. R. Soc. Esp. Hist. Nat. (Biol.) 1971, $69,11-18$.

42. Pérez-Iñigo, C. Biospeleología de la cueva Ojo Guareña. Acaros oribátidos. Bol. R. Soc. Esp. Hist. Nat. (Biol.) 1969, 67, 143-160.

43. Prieto, C.E.; Gómez, B.J. Primeros datos de Zospeum (Mollusca, Gastropoda, Ellobiidae) para la provincia de Burgos. Com. $2^{\circ}$ Simp. Reg. Espeleol. Burgos 1984, 143-147.

44. Demange, J.M.; Serra, A. Etude des rapports de longueur des articles des P.15 de quelques Lithobius cavernicoles de l'Espagne et des Pyrénées françaises. Description d'une espèce et une sous-espèce nouvelles (Chilopoda, Lithobiomorpha). Speleon 1978, 24, 39-54.

45. Rambla, M. Contribución al estudio de los Opiliones de la Fauna Ibérica. Las especies del grupo nemastoma bacilliferum, Simon, 1879 en la Península Ibérica (Opiliones, Fam. Nemastomatidae). Publ. Inst. Biol. Aplic. 1968, 45, 33-56.

46. Prieto, C.E.; Zubiaga, A. El género Ischyropsalis C.L. Koch (Ischyropsalididae, Opiliones) en la provincia de Burgos. Mem. $2^{\circ}$ Simp. Reg. Espeleol. Burgos 1984, 15-19. 
47. Español, F. Un nuevo Trechus cavernícola del norte de Burgos (Col. Trechidae). Speleon 1970, XVII, 53-57.

48. Mösslacher, F. Evolution, Adaption und Verbreitung. In Grundwasseroökologie; Griebler, C., Mösslacher, F., Eds.; UTB-Facultas Verlag: Wien, Austria, 2003; pp. 253-310.

49. Culver, D.C.; Christman, M.C.; Sket, B.; Trontelj, P.P. Sampling adequacy in an extreme environment: Species richness patterns in Slovenian caves. Biodivers. Conserv. 2004, 13, 1209-1229. [CrossRef]

50. Bregovic, P.; Zagmajster, M. Understanding hotspots within a global hotspot-Identifying the drivers of regional species richness patterns in terrestrial subterranean habitats. Insect Conserv. Biodivers. 2016, 9, 268-281. [CrossRef]

51. Gibert, J.; Deharveng, L. Subterranean ecosystems: A truncated functional biodiversity. Bioscience 2002, 52, 473-481. [CrossRef]

52. Griebler, C.; Mösslacher, F. Grundwasser-eine ökosystemare Betrachtung. In Grundwasserökologie; Griebler, C., Mösslacher, F., Eds.; UTB-Facultas Verlag: Wien, Austria, 2003; pp. 253-310.

53. Hahn, H.J. The GW-Fauna-Index: A first approach to a quantitative ecological assessment of groundwater habitats. Limnologica 2006, 36, 119-137. [CrossRef]

54. Stoch, F.; Galassi, D.M.P. Stygobiotic crustacean species richness: A question of numbers, a matter of scale. Hydrobiologia 2010, 653, 217-234. [CrossRef]

55. Camacho, A.I.; Mas-Peinado, P.; Dorda, B.A.; Casado, A.; Brancelj, A.; Knight, L.R.F.D.; Hutchins, B.; Bou, C.; Perina, G.; Rey, I. Molecular tools unveil an underestimated diversity in a stygofauna family: A preliminary world phylogeny and updated morphology of Bathynellidae (Crustacea: Bathynellacea). Zool. J. Linn. Soc. 2018, 183, 70-96. [CrossRef]

56. Zagmajster, M.; Malard, F.; Eme, D.; Culver, D.C. Subterranean biodiversity patterns from global to regional scales. In Cave Ecology, Ecological Studies 235; Moldovan, O.T., Kovác, L., Halse, S., Eds.; Springer: Cham, Switzerland, 2018 ; pp. 195-228.

57. Deharveng, L.; Bedos, A. The cave fauna of southeast Asia. Origin, evolution, and ecology. In Subterranean Ecosystems; Wilken, H., Culver, D.C., Humphreys, W.F., Eds.; Elsevier: Amsterdam, The Netherlands, 2000; pp. 603-632.

58. Pipan, T.; Deharveng, L.; Culver, D.C. Hotspots of Subterranean Biodiversity. Diversity 2020, 12, 209. [CrossRef]

59. Camacho, A.I. Diversity, morphological homogeneity and genetic divergence in a taxonomically complex group of groundwater crustaceans: The little known Bathynellacea (Malacostraca). Bull. Soc. d'Hist. Nat. Toulouse 2019, 154, $105-160$. 